\title{
MIGRATION, ETHNICITY AND LOCAL POLITICS: THE CASE OF JAKARTA, INDONESIA
}

\author{
Aulia Hadi and Riwanto Tirtosudarmo \\ Research Center for Society and Culture, Indonesian Institute of Sciences \\ Correspondence: Aulia Hadi (email: aulia.hadi.mulyo@gmail.com)
}

\begin{abstract}
As the capital city of a country with the world's fourth largest population, Jakarta, like many other big cities in the developing economies, for example, Mexico City or New Delhi, hosts migrants from all regions of the country. Without a doubt, Jakarta has increasingly become the major core of the agglomeration processes transforming it and its satellite cities into a Mega Urban Region (MUR). This paper traces historically the interactions between migration, ethnicities and local politics in Jakarta from the 1960s to the 2000s focusing on the latest development, in which the phenomenon 'Ahok', the nickname of Basuki Tjahaja Purnama, a Chinese-Christian from the small district of Belitung, has become an increasingly popular Governor of Jakarta. The paper argues that through the recent developments in Jakarta the politics have apparently been transformed into more civic, rather than ethnic politics. The nature of Jakarta as a proliferating migrant city transcends narrow cultural identities as well as conventional party politics into a more active citizenry through the widespread use of social media.
\end{abstract}

Keywords: migration, ethnicity, local politics, new media

\section{Introduction}

The interconnection between migration, ethnicity and politics has been thoroughly studied, among others, by Fearon and Laitin (2011). In the case of Indonesia, the recent study by Barter and Cote (2015) clearly shows that local political conflicts closely related with the increasing number of migrants are perceived by the locals as a threat to their livelihoods. As the capital city of the world's fourth largest population country, Jakarta, like many other big cities in the developing economies, for example, Mexico City or New Delhi; hosts migrants from all the regions of the country. The arrival of migrants to Jakarta had already started in the $17^{\text {th }}$ century. Because of the low number of inhabitants, the Government of the Dutch East Indies encouraged people to move to Batavia ${ }^{1}$ to meet its labour needs. The migrants were not only from Java's hinterland (such as Javanese and Sundanese ethnic groups) or outside of Java (such as Balinese, Bugis, Batak and Ambonese), but also from the Far East (such as Japanese and Chinese people) and South Asia (such as Arabs and Indians) (Castles, 1967 and Abeyasekere, 1987). Those ethnic groups then merged into what was called

\footnotetext{
1 Batavia was the name of the Dutch East Indies' capital city. At that time, it became the center of the Dutch East Indies trading network in Asia, including black pepper, cloves and cinnamon. Now the area corresponds to the city of Jakarta.
} 


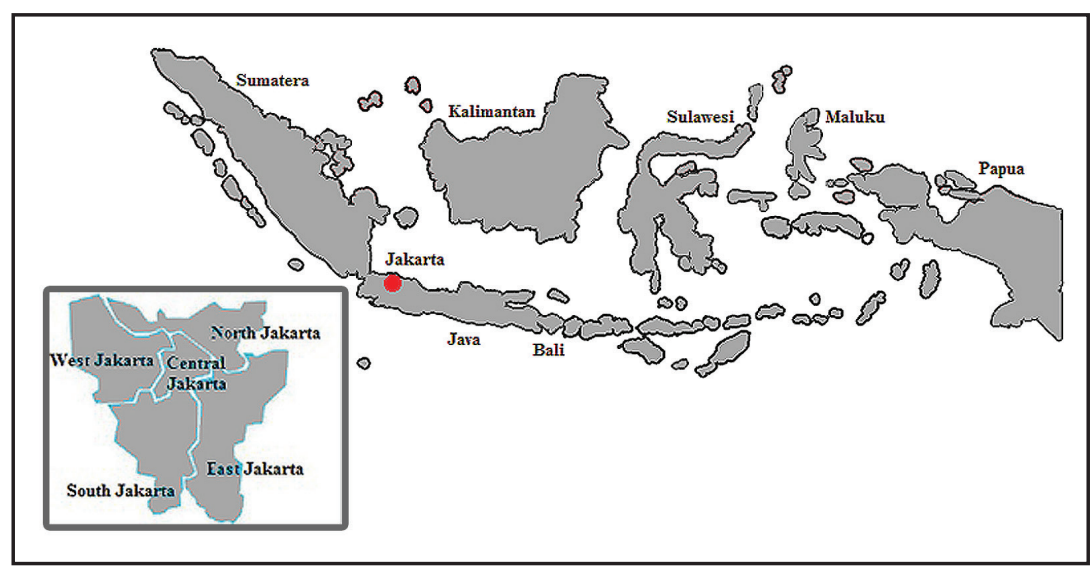

Source: http://www.inspired-bali.com/wp1/50-years-in-indonesia/, in which the grey colour, the red dot and the insert of Jakarta are modified by the authors

Picture 1 Map of Indonesia with Jakarta Insert

Batavian or Betawi or Djakarta Asli (Castles, 1967). With Jakarta as the capital, the number of migrants has increased significantly since the Independence of Indonesia in 1945. Without a doubt, Jakarta has developed as the major core of the agglomeration processes transforming the city and its satellite cities into a Mega Urban Region (MUR). ${ }^{2}$ The migrants disperse to the satellite cities, therefore, the number in Jakarta has decreased since the mid1990s. However, Jakarta has the most diverse ethnic mix in Indonesia with 9,607,787 inhabitants (Population Census of Indonesia, 2010).

In September 2012, surprisingly Jokowi (Joko Widodo) and his running mate Ahok (Basuki Tjahaja Purnama) won victory in Jakarta's 2012 Gubernatorial Elections. With $54 \%$ of votes, these candidates successfully beat the incumbent, Foke (Fauzi Bowo) and Nara (Nachrowi Ramli) who are both native

\footnotetext{
2 In this article, we consider Jakarta as a city. In fact, we should note that administratively since the 1950s Jakarta has been governed not as a city, but as a province called Daerah Khusus Ibukota Jakarta or the Special Capital Territory of Jakarta, comprising five cities and one district (Bunnell \& Miller, 2012). Furthermore, since the 1970s during the centralized New Order regime emphasizing economic growth, Jakarta has been developed into a MUR called Jabodetabekjur incorporating Bogor, Depok, Tangerang, Bekasi and Cianjur (Firman, 2008 and 2009; Windarsih and Hadi, 2014).
}

Betawi Muslims. Since the end of the New Order regime in 1998, the decentralization governance system has provided greater 'power' for both the regional governments and the people to manage their city or region, including by participating in direct regional elections. In fact, local politicians in many areas are mostly reliant on the support of religious leaders considered able to get large numbers of votes (Kloos \& Berenschot, 2016). This certainly put a heavy burden on Jokowi, a Muslim Javanese from Solo and Ahok, a Christian Chinese-Indonesian from the small district of Belitung, who both are migrants to Jakarta. Despite negative ethnoreligious campaigns against them, Miichi (2014) describes their victory as a triumph of democracy, particularly for the Jakartans.

In 2014, since Jokowi was elected president in October, Ahok was inaugurated as Jakarta's new governor in November, amidst protests from the supporters of the losing presidential candidate, Prabowo Subianto, and hard-line Islamic groups. In his early days as the Governor of Jakarta, Ahok experienced opposition from the House of Representatives in terms of contravening the gubernatorial appointment rules as well as budget transparency. Ahok pays great attention to managing the governance system, including 
planning the dismissal of underachieving civil servants and introducing e-budgeting for transparency, as well as asking property owners to pay fines enabling him to conduct various projects in a short period of time. Therefore, with the bureaucracy of Jakarta becoming much less cumbersome, Ahok is gaining popularity among the Jakartans despite his harsh attitudes. Banking on this popularity, Ahok is certain to run in the next Jakarta Gubernatorial Elections in 2017.

This article discusses the changing role of ethnicity in Jakartans' public life as well as its consequences to the local politics. To some extent the democracy of Indonesia might be a paradox between freer and fairer public space and patronage democracy (Berenschot, Nordholt \& Bakker, 2016). As highlighted by Berenschot, Nordholt and Bakker (2016), a weakly institutionalized state and mediated access to the state in most of the postcolonial states, including Indonesia, encourage client centered and often identitybased relationships with politicians and other power holders. Therefore organizations, such as ethnic or faith based ones, can be useful lubricants for the client centered exchanges. However, we argue that the recent political developments in Jakarta have apparently been transformed into more civic rather than ethnic politics. The nature of Jakarta as a proliferating migrant city transcends narrow cultural identities as well as conventional party politics into a more active citizenry through the widespread use of social media. In the heat of Jakarta's 2017 Gubernatorial Election, for the first time in history, the front-runner is a Christian Chinese-Indonesian. Since Jakarta is the center of national politics, this new kind of local politics will exemplify substantial democracy for other cities in Indonesia.

The aim of this article is to comprehend the ways migration and ethnic diversity have transformed Jakarta as a city of migrants and the consequences to the local politics. We start by providing some historical context to interpret the nature of Jakarta as a host city of migrants from various ethnic groups. Then, we draw the dynamics of ethnicity and provincial leadership in Jakarta from 1945 to the present. In the third part, we describe the recent Jakarta local politics with an emphasis on Ahok and his political manoeuvers, including the establishment of 'Teman Ahok' (Friend $\{s\}$ of Ahok) as the social media political campaign platform. Later, we discuss the political contestation for the upcoming Jakarta Gubernatorial Elections. The conclusion highlights to what extend the civic politics is likely to work in Jakarta.

\section{Ethnic Composition of Jakarta}

Since its establishment in 1619 by Jan Pieterszoon Coen, Jakarta has become a very attractive city (Abeyasekere, 1987). At that time, the economic activities of Jakarta were extensive and included farming, plantations, the sugarcane industry as well as brick and roof tile production (Kanumoyoso, 2007) attracting people to move to Jakarta because of the numerous job opportunities. As mentioned, these migrants were from Java's hinterland and various parts of the Archipelago, as well as from East and South Asia. According to Kanumoyoso (2007), the ethnic identity of migrants in Batavia was getting blurred because of (a) socio-economic interests and geographical proximity, (b) intermarriage among various ethnic groups, (c) common experiences in the military service of the Vereenigde Oostindische Compagnie (VOC), (d) religious identity, and (e) slavery institutions enabling migrants to work in a multi-ethnic environment. The presence of various ethnic groups created Batavia and then Jakarta as a multi-ethnic city.

Since the Independence of Indonesia in 1945, the composition of the ethnic groups in Jakarta as a host city of migrants has changed tremendously. While previously, Jakarta welcomed migrants from Europe as well as East and South Asia, their number has 
significantly decreased in the post-colonial period. In the period from 1945 onwards, the migrants to Jakarta have been from various ethnic groups in the Indonesian Archipelago. This was firstly shown in the data of the 1961 Population Census when no ethnic group question was asked explicitly. However, within this, Castles (1967) made a calculation based on the birth place of migrants in Jakarta. He also assumed that everyone in Jakarta in 1961 was either (a) a survivor or descendant of the 1930 population or (b) an immigrant since 1930 or a descendant of such an immigrant (pp. 154). From his calculation, the main ethnic groups forming Jakarta were Sundanese, Javanese, and Madurese, Betawi

Table 1 Ethnic Composition of Jakarta

\begin{tabular}{|c|c|c|c|c|c|c|}
\hline \multirow{3}{*}{ Ethnic Group } & \multicolumn{6}{|c|}{ Population Census } \\
\hline & \multicolumn{2}{|l|}{$1961^{3}$} & \multicolumn{2}{|c|}{2000} & \multicolumn{2}{|l|}{2010} \\
\hline & Number & $(\%)$ & Number & $(\%)$ & Number & $(\%)$ \\
\hline Betawi & 655,400 & 22.9 & $2,301,582$ & 27.65 & $2,700,722$ & 28.29 \\
\hline Sundanese & 952,500 & 32.8 & $1,271,531$ & 15.27 & $1,395,240$ & 14.61 \\
\hline Javanese \& Madurese & 737,700 & 25.4 & - & - & - & - \\
\hline Javanese & - & - & $2,927,340$ & 35.16 & $3,452,168$ & 36.16 \\
\hline Madurese & - & - & 47,055 & 0.57 & 79,925 & 0.84 \\
\hline Bantenese & - & - & 20,582 & 0.25 & - & - \\
\hline Acehnese & 5,200 & 0.2 & - & - & - & - \\
\hline Batak & 28,900 & 1.0 & 300,562 & 3.61 & 326,645 & 3.42 \\
\hline Minangkabau & 60,100 & 2.1 & 264,639 & 3.18 & 272,018 & 2.85 \\
\hline South Sumatran & 34,900 & 1.2 & - & - & - & - \\
\hline Palembangnese & - & - & - & - & 63,333 & 0.66 \\
\hline Banjarnese & 4,800 & 0.2 & 7,977 & 0.10 & - & - \\
\hline South Sulawesianese & 17,200 & 0.6 & - & - & - & - \\
\hline Bugis & - & - & 49,426 & 0.59 & 68,366 & 0.72 \\
\hline North Sulawesianese & 21,000 & 0.7 & - & - & - & - \\
\hline Mollucan \& Irianese & 11,800 & 0.4 & - & - & - & - \\
\hline $\begin{array}{l}\text { East Nusa } \\
\text { Tenggaranese }\end{array}$ & 4,800 & 0.2 & - & - & - & - \\
\hline $\begin{array}{l}\text { West Nusa } \\
\text { Tenggaranese }\end{array}$ & 1,300 & 0.0 & - & - & - & - \\
\hline Balinese & 1,900 & 0.1 & - & - & - & - \\
\hline $\begin{array}{l}\text { Malay and from other } \\
\text { islands }\end{array}$ & 19,800 & 0.7 & 134,477 & 1.62 & 111,125 & 1.16 \\
\hline Unknown & 38,600 & 1.3 & - & - & - & - \\
\hline Chinese & 294,000 & 10.1 & 460,002 & 5.53 & 632,372 & 6.62 \\
\hline Others & 16,500 & 0.6 & 539,529 & 6.48 & 445,627 & 4.67 \\
\hline Total & $2,906,500$ & 100.0 & $8,324,707$ & 100.00 & $9,547,541$ & 100.00 \\
\hline
\end{tabular}

3 In his calculation, Castles (1967) distinguished non-indigenous people into two categories, namely (a) hybrid or citizenship replacement people and (b) foreigners. On his data, he calculates that there were around 102,000 Chinese foreigners among 294,000 Chinese in Indonesia. He also adds that of the 16,500 from other ethnic groups in the 1961 Population Census, there were at least 10,200 foreigners. 
and Chinese consecutively as presented in Table 1. In 1971, 1980 and 1990 population censuses, the question of ethnicity was erased from the questionnaire due to the New Order Government perception that statistics on ethnicity could be divisive for national integration.

While data on ethnic groups was considered politically taboo by the New Order regime, this question is reinstated in the Population Census in the reformasi period. Indonesia consists of various ethnic groups and local languages; therefore, understanding those diversities is part of establishing Bhinneka Tunggal Ika or Unity in Diversity in our nation. From Population Censuses in 2000 and 2010, we can observe that the four major ethnic groups in Jakarta remain Betawi, Sundanese, Javanese and Chinese followed by Batak, Minangkabau and Malay (Table 1). However, the number of Sundanese is decreasing if compared with the 1961 Population Census. This puts Sundanese only in the third rank following Javanese and Betawi. Meanwhile, the number of people of Chinese ethnicity consistently stays in the fourth place. The other sizable ethnic groups in recent Jakarta are Bugis, Madurese, Palembangnese, Bantenese and Banjarnese. We can observe some homogeneous areas with a big number of concentrated ethnic groups, such as Chinese in the Glodok and Mangga Dua areas, Bugis in the Tanjung Priok area and (previously) Betawi in the Condet area. In fact, Betawi at the present time mostly live dispersed in the fringe suburban areas around Jakarta in keeping with their socio-economic status.

The trends of the 1961, 2000 and 2010 Population Censuses show the contribution of migration to the ethnic composition of Jakarta. The presence of migrants in Jakarta emphasizing socio-economic relationships makes the ethnic identity vaguely create a multi-ethnic city. In recent days, Jakartans mostly prefer to speak Bahasa Indonesia in their own style rather than their mother languages and perceive themselves as the representatives of Indonesia. ${ }^{4}$ Castles (1967: 153) even claimed Jakarta as the 'melting pot' for various ethnic groups as well as 'the mosteven the only-Indonesian city', where 'God is making the Indonesians!' Since the Jakartans are mostly cosmopolite migrants, we argue that civic rather than ethnic politics is getting popular among them as discussed in the following parts.

\section{Ethnicity and the Provincial Leadership of Jakarta}

The leadership of Jakarta is crucial for Indonesia as it is the capital city of the country. The political situation of Jakarta will always be a reference for other cities in Indonesia and a barometer for the national politics. Ethnic politics seem to have never been in favour for most Jakartans, particularly in the current democracy era. These are at least reflected in three political regimes of Indonesia, namely Old Order, New Order and reformasi.

During the Old Order regime (1945-1965), Jakarta was mostly governed by national political figures. Soekarno as the first President of Indonesia, who was also a national leader for the Independence of Indonesia,

4 “... Eeh Nok, lu pan jelek-jelek anak Jakarte, masa segala neken aje nggak becus? Malu-maluin gue aja lu ah!" kata bang Amat serenta cabut kartu penduduknya dari kantong atas, "Nih kaye gue, kalo ude punye pan enak!"... "Nama... Amat bin Conat," untuk kesekian kalinya bang Amat membaca kartu penduduknya kencang-kencang, "Bangsa ... Indonesia! Agama ... Selam eh Islam!” (Muntaco, 2006: 251-252). [“... Nok, you are Jakartan. How can't you make your own signature? That's a shame," bang Amat said to his wife while taking out the ID card from his pocket. "It's nice when we've had it, just like me!" .... "Name ... Amat bin Conat," for the umpteenth time bang Amat read his ID card loudly, "Nation ... Indonesia! Religion ... Selam eh Islam!"]. This dialogue narrates the typical language spoken by the Jakartans combining Bahasa Betawi as the language of the "indigenous people" and Bahasa Indonesia. Not only multi-ethnic, but also the Jakartans perceive themselves as the centre of Indonesia, therefore, they need to be foremost in everything, such as being literate and active in civic participation as in the above story. 
encouraged the growth of nationalism for Indonesians, especially Jakartans. He not only built national projects, such as the National Monument in the centre of Merdeka Square, Central Jakarta, but also appointed national political figures as mayors of Jakarta. Only two out of the six mayors of Jakarta in this period were non-Javanese. They were Daan Jahja, from Padang and Henk Ngantung, from the Minahasa ethnic group. Rather than ethnicity, most of these mayors were appointed because of their political affiliation and credibility. The mayors of Jakarta during the Old Order regime were affiliated with the winning parties in national elections, both Partai Nasional Indonesia (PNI) (Indonesian National Party) led by Soekarno and Partai
Majelis Syuro Muslimin Indonesia (Masyumi) (Council of Indonesian Muslim Associations) incorporating Nahdlatul Ulama (NU) and Muhammadiyah as the two biggest Islamic mass organizations in Indonesia.

All governors of Jakarta in the New Order regime (1965-1998) were from the military, which reflects the authoritarian character of the New Order regime. Under the leadership of President Suharto, the second president, who led Indonesia for 32 years, the governors of Jakarta were only those having proximity as well as following his rules. The most popular governor in this time was Ali Sadikin, the only non-Javanese. This Sundanese was the longest serving governor of Jakarta, from

Table 2 Governors of Jakarta: 1945-Present ${ }^{5}$

\begin{tabular}{|c|c|c|c|c|}
\hline No. & Name & Year & Ethnic Group & Affiliation \\
\hline 1. & Soewirjo & $1945-1947$ & Javanese & Partai Nasional Indonesia (PNI) \\
\hline 2. & Daan Jahja & 1948-1950 & Padang & Military \\
\hline 3. & Soewirjo & $1950-1951$ & Javanese & Partai Nasional Indonesia (PNI) \\
\hline 4. & Sjamsuridjal & $1951-1953$ & Javanese & Masyumi \\
\hline 5. & Soediro & $1953-1960$ & Javanese & Government Appointment \\
\hline 6. & $\begin{array}{l}\text { Soemarno } \\
\text { Sosroatmodjo }\end{array}$ & $1960-1964$ & Javanese & Military \\
\hline 7. & Henk Ngantung & 1964-1965 & Minahasa & Government Appointment \\
\hline 8. & $\begin{array}{l}\text { Soemarno } \\
\text { Sosroatmodjo }\end{array}$ & $1965-1966$ & Javanese & Military \\
\hline 9. & Ali Sadikin & 1966-1977 & Sundanese & Military \\
\hline 10. & Tjokropranolo & 1977-1982 & Javanese & Military \\
\hline 11. & Soeprapto & 1982-1987 & Javanese & Military \\
\hline 12. & $\begin{array}{l}\text { Wiyogo } \\
\text { Atmodarminto }\end{array}$ & 1987-1992 & Javanese & Military \\
\hline 13. & Soerjadi Soedirdja & 1992-1997 & Javanese & Military \\
\hline 14. & Sutiyoso & $1997-2007$ & Javanese & Military \\
\hline 15. & Fauzi Bowo & 2007-2012 & Betawi & Partai Demokrat \\
\hline 16. & Joko Widodo & $2012-2014$ & Javanese & $\begin{array}{l}\text { Partai Demokrasi Indonesia } \\
\text { Perjuangan (PDI-P) }\end{array}$ \\
\hline 17. & $\begin{array}{l}\text { Basuki Tjahaja } \\
\text { Purnama }\end{array}$ & 2014-present & $\begin{array}{l}\text { Chinese- } \\
\text { Belitung }\end{array}$ & Government Appointment \\
\hline
\end{tabular}

Source: Compiled by the authors, based on the data provided by Panitia Penulisan Gubernur Jakarta, 2011.

\footnotetext{
5 Jakarta was firstly governed as a city in the period of 1945-1960 by the Mayor Soewirjo, Mayor Daan Jahja, Mayor Sjamsuridjal and Mayor Soediro. Since then, Jakarta has been governed as a province.
} 
1966 to 1977 . He is considered a modernist, who transformed Jakarta into a modern city through various programs, such as improving public services, banning becak (cycle rickshaw), clearing out the slum dwellers, kampungisasi, encouraging urban dwellers to reinvest in the traditional value of gotong royong (mutual cooperation) with modern ones, creating Jakarta Fair -a month long peoples' bazaar (continued until now) as well as building mega projects, such as Taman Ismail Marzuki, Ragunan Zoo and the Ancol Amusement Park. Although Jakarta had one of its greatest governors in this period, the strong power of the New Order regime through their military governors reproduced the 'patronclient relationship' in Jakarta rooted to other cities in Indonesia. The relationships between the patron or the collusion between politicians, bureaucrats and business dominated the networks and distributed large sums of money in exchange for loyalty from the clients or what is called by Berenschot, Nordholt \& Bakker (2016) 'clientilistic exchange relations.'

Democracy is the strongest attribute of reformasi (1998-present). In this regime, Indonesians insist on the decentralization of government. Based on Law No. 32 Year 2004 on Regional Autonomy, the citizens have the right to manage their own regional government as well as voting for their regional leader directly. While in the beginning of reformasi Jakarta was still governed by Sutiyoso for ten years, afterwards the Jakartans voted for their governor directly. At the first Jakarta Gubernatorial Election, it was Fauzi Bowo, a native Betawi Muslim, who gained the majority of votes. Rather than ethnicity reasons, we assume his victory was a form of proximity and affiliation with the ruling regime, President Susilo Bambang Yudhoyono, who is also the chairman of Partai Demokrat (Democratic Party). In the context of democracy, the dynamics of Jakarta's local politics have heated up since Jakarta's 2012 Gubernatorial Elections bringing 'a new hope to politics'. Jokowi's victory is evidence of populism politics in Jakarta. As highlighted by Hamid
(2014), the four factors enabling the rise of Jokowi's popularity are (1) social breakdown and declining capability of the government; (2) corruption, draining political traditions and the negative image of political parties; (3) societal changes; and (4) the emergences of forms of political representation outside of traditional political institutions. As Jokowi was voted in to be the President of Indonesia in the 2014 Presidential Elections, Ahok was appointed as Jakarta's Governor in the same year. Following his predecessor Jokowi, Ahok has continuously reformed the city governance making him the most popular, yet controversial Governor of Jakarta as will be discussed in the next part.

\section{Jakarta's Recent Local Politics: Ahok and His Political Manoeuvers}

As widely reported, in 2016 Ahok was the most searched person on Google in Indonesia. This Christian Chinese-Indonesian Governor of Jakarta has not only been popular among his adherents, but also with the opposition since he has led the city from November 2014. His popularity seems to result from his 'double-minority status' as well as his blunt communications style. Firstly, Ahok is a Chinese-Indonesian migrant from Manggar, East Belitung, who first moved to Jakarta to study for his senior high school accreditation then his bachelor degree at the end of the 1980s. Although the Chinese ethnic group stays in the fourth place of Jakarta's ethnic composition, this ethnic group remains politically discriminated against. Secondly, he is a Christian in Muslim-majority Jakarta. Furthermore, Ahok frequently criticizes and scolds not only his subordinates of assorted wrongdoing, but also expresses his stance, particularly any disagreement, directly to the public in general.

Ahok started his political career since reformasi. At first he was affiliated with a new party: Partai Perhimpunan Indonesia Baru 


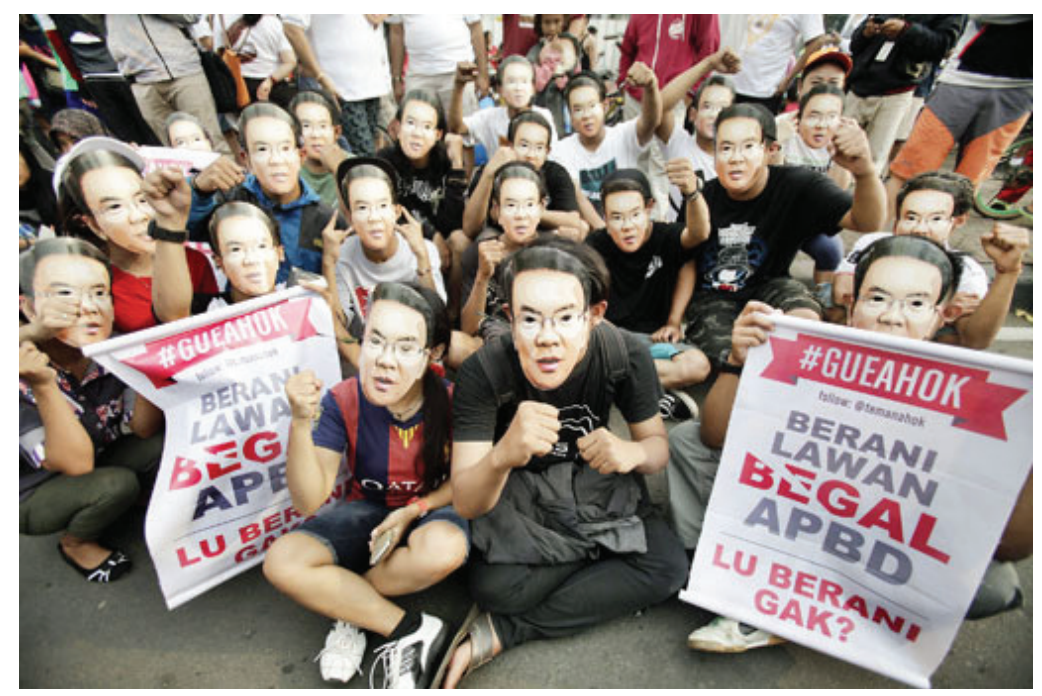

Source: www.thejakartapost.com

Picture 2 A Peaceful Rally to Support Ahok against the City Councils

Table 3 Online Activities of Teman Ahok

\begin{tabular}{llr}
\hline No. & \multicolumn{1}{c}{ New Media } & \multicolumn{1}{c}{ Followers } \\
\hline 1. & Website temanahok.com & \\
2. & Twitter @temanAhok & 97,330 followers; 22,325 tweets \\
3. & Facebook page @temanahok & 400,203 likes \\
4. & Youtube Teman Ahok & 17,489 subscribers; $2,969,996$ views \\
5. & Instragram temanahokofficial & 154,000 followers \\
\hline
\end{tabular}

Source: Compiled by the authors, based on the data provided on social media accounts of Teman Ahok.

(PPIB) and became a member of the Regional Legislative Council of East Belitung District for 2004-2009. Only seven months later, he gained huge support to run for regent of the same district. He won with $37.13 \%$ votes in the politically based area of Masyumi and became the Regent of East Belitung for 20052010. In 2009, he was elected as the Member of the House of Representatives in Jakarta, representing Golongan Karya (Golkar). He then resigned to be the running mate of Jokowi in Jakarta's 2012 Gubernatorial Elections as a member of Gerakan Indonesia Raya (Gerindra). When his predecessor, Jokowi, was elected President of Indonesia, Ahok resigned from Gerindra in September 2014 or before his inauguration as governor; therefore, he acts as a politically independent governor of Jakarta. This political manoeuvre enabled him to separate himself from the oligarchic powerful national elites in the political parties. He can carry out a lot of development projects relatively quickly by asking, mostly property owners, to pay 'fines', for such as the Semanggi interchange as well as Northern Jakarta's coast reclamation.

Implementing budget transparency was the second manoeuver of Ahok. In the beginning of 2015, the use of e-budgeting, namely kawalapbd.org, allowed Ahok to find an irregularity or misuse in Jakarta's regional budget, which cost the nation around Rp12 trillion (Pradita, 2015). Ahok became entangled 
in argument with the City Councils receiving many attacks from the elites, including that involving the case of land acquisition in West Jakarta from the Sumber Waras Hospital by the city administration (The Jakarta Post, 14 June 2016), at the same time people came up with various social media hashtags and movements supporting him (Dwifatma, 2015). Rather than shrinking, Ahok is perceived as 'clean'; an honest, strong leader fighting corruption, therefore, his popularity has soared rapidly.

Ahok's third manoeuver was announcing his plan to join the Jakarta 2017 Gubernatorial Elections through an independent path distanced from political parties. This certainly creates empathy among his adherents who endorse his position with no political party affiliations. First, during the Car Free Day at the Hotel Indonesia traffic circle in Central Jakarta, on 1 March 2015, a group of people wore masks of Ahok to support him over the draft 2015 city budget (Picture 2). This was the inception of Teman Ahok (Friend\{s\} of Ahok) movement established on 16 June 2015, by five young people, namely Aditya Yogi Prabowo, Richard Saerang, Singgih Widiyastono, Amalia Ayuningtyas and Muhammad Fathony. ${ }^{6}$ The main activity of this movement was primarily to collect Jakartans' ID cards as a way of supporting Ahok's independent candidacy in the next gubernatorial elections, when at least 750,000 ID cards are needed. Initiated by the young, Teman Ahok combines traditional media (including posts, booths, hotlines and gatherings) and new media (including website temanahok.com, Twitter, Facebook, Youtube and Instagram) on their movement (Table 3).

New media is the first tool for Teman Ahok to attract public engagement. The website is used

\footnotetext{
6 This movement firstly received assistance from political consultancy institutions, particularly the CEO of the Cyrus Network, Hasan Nasbi, who works in collaboration with Sunny Tanuwidjaja, an unpaid political staffer for Ahok. Hasan trained them in campaign strategy, provided a building as a post and gave Rp500 million for initial preparations (Purnomo, Aprianto \& Ernis 2016). Later, they started to sell merchandise to finance their movement.
}

to provide information about Ahok, including personals, performances and achievements. It also counts down the total update of collected Jakartan ID cards. Meanwhile, the massive use of the social media is effective to gain the public's attentions; mostly of the young and the middle class. They then interconnect the online and the offline spaces through posts, booths built in several malls, such as Mall Kelapa Gading and Kuningan City, as well as other public gathering places. This can be categorized as digital activism that is internet supported with a low threshold (Van Laer and Van Aelst, 2010). The internet or new media only supports the movement. The public is required to participate directly by handing over their ID cards and giving signatures as support agreements. This certainly has lower risks for most participants. Starting on 15 June 2015, they eventually were able to collect 1 million vote pledges a year after. Ahok's decision to jump to a political party leads this movement as Tetap Ahok.

The last manoeuver of Ahok was leaving the independent path and jumping on a political party bandwagon at the end of July 2016. Towards the candidate registration period, Ahok received political parties' support, including from the Indonesian Democratic Party of Struggle (PDI-P), the Golkar Party, the People Conscience Party (Hanura) and the National Democratic Party (Nasdem). Ahok emphasizes that his volunteers at Teman Ahok have agreed with and support his decision.

Ahok's political manoeuvers have always been controversial. His steps of being an independent governor, having a clash with the City Council on the budget draft and prioritizing an independent path in gubernatorial elections certainly have 'shaken' the country's political establishment. The voluntarism of Teman Ahok to some extent shows Ahok's strategy to demonstrate his mass support to the political parties. The decentralization in reformasi has further enhanced oligarchy in Indonesia, with local and national politicians cooperating with 
bureaucrats and business, to implement as well as manipulate policies and laws to their needs (Hadiz, 2010 and Berenschot, Nordholt \& Bakker, 2016). Ahok's manoeuvers certainly brought 'trouble' to those oligarchic national political elites. Just like Bersih in Malaysia (Lim, 2016), these manoeuvers encourage the public, particularly the youth in Teman Ahok, to engage in wide civic politics.

\section{Political Contest for the Upcoming Jakarta 2017 Gubernatorial Elections}

At the beginning of 2016, Ahok was topping the electability survey for Jakarta's 2017 Gubernatorial Elections. From the poll conducted by the Indonesia Survey Institute (LSI) for example, on March 2016 his electability reached $59.3 \%$ leaving other candidates behind (Tempo, 21-27 November 2016: 34-35). As reported by Tempo, his electability decreased slightly to $49.1 \%$ when he decided to jump on the political party bandwagon at the end of July 2016. In fact, Ahok enjoyed a comfortable gap in most surveys until he registered as gubernatorial candidate with Djarot Saiful Hidayat as his running mate.

The political contestation heated up at the end of September 2016 because of Ahok's controversial blasphemy case. The case began when Ahok delivered a speech during a visit to the Kepulauan Seribu Regency citing Surah al-Maidah, verse 51 of the Quran. It states that Muslims should not vote for nonMuslims as leaders. A short clip portraying Ahok as joking and telling the locals not to be lied to by political leaders using that surah went viral after it was edited and a comment added. Alas, the Indonesian Ulema Council (MUI) considers it to be blasphemy and has urged the police to handle this case. Furthermore, the hard-line group, Islamic Defenders Front (FPI) has filed a complaint against Ahok with the police.

Protest and support abounded in response to Ahok's blasphemy. Spearheaded by the FPI leader, Habib Rizieq, the National Movement to Safeguard the Indonesian Ulema Council's Fatwa (GNPF MUI) organized three rallies to demand the arrest of Ahok. The rallies on 14 October, 4 November and 2 December consecutively aimed to urge the police to investigate, prosecute and incarcerate Ahok. During the movement, people wearing white flocked downtown. The second rally even ended with a riot. The movement abated when the National Police Criminal Investigation Department named Ahok a suspect in a blasphemy case on 16 November. Meanwhile, Ahok's adherents held a Bhinneka Tunggal Ika parade, citing the national motto meaning

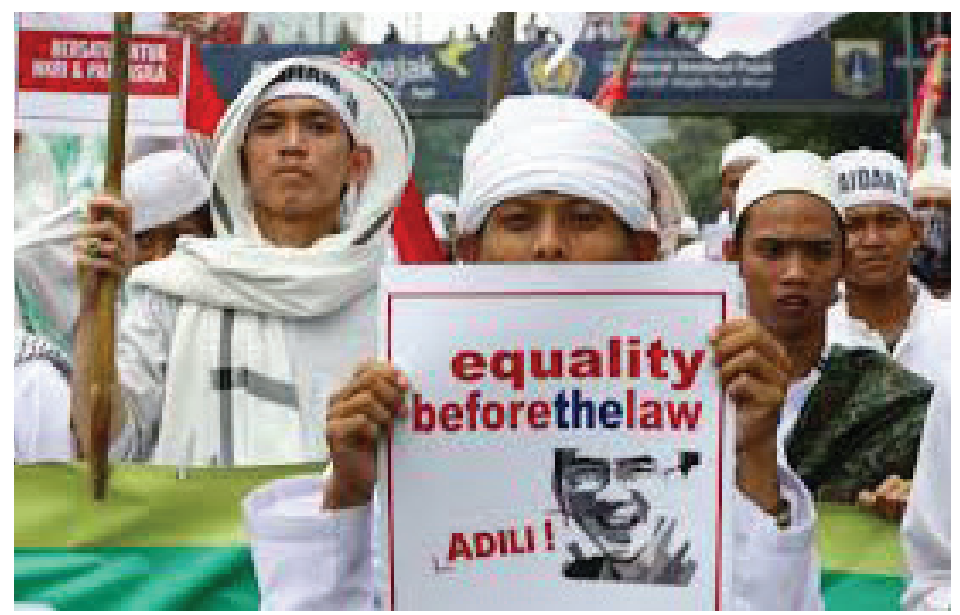

Source: www.thejakartapost.com

Picture 3 The $4^{\text {th }}$ November Rally against Ahok's Blasphemy 
Table 4 Examples of Hate Speech on \#DoaUntukAhok (\#Pray for Ahok)

\begin{tabular}{ll}
\hline Anti-Ahok & Pro-Ahok \\
\hline nahhh kalo alesan dia gusur karna itu bukan & Ngoceh comberan? Lo bs gak belajar \\
tanah milik warga, ngapain si ahok ngoceh & bahasa indonesia yg baik dan benar dlu. \\
comberan tentang ayat dari kitab suci yang & Ngomong aja kyk org gak sekolah mau \\
bukan "milik dia" yg dalam hal ini enggak dia & komentarin org lain. Manusia tolol kyk lo \\
imani?!!! Lu tuh yg bego!!! Hahaha bego lu!!! & ini ni yg hrs nya musnah dr ina. Perusak \\
[If Ahok evicted the people living not on & moral dan penghasut tnpa tau apa2. Alias \\
their lands, then why he delivered wanton & tong kosong, gunain dlu hidup lo bt org \\
speech using Quran that is not belong to & lain deh.. berguna jg enggak lu \\
him? Such an idiot!!! ...] & [Delivered wanton speech? Can you speak \\
& Bahasa Indonesia in good and right ways? \\
& You speak as if you aren't educated, but \\
& deserve to criticize others. Such stupid \\
& person like you should be annihilated \\
& from Indonesia. You are moral destroyer \\
\hline Haha emang nya anda tau saya demo & and provoker. ...] \\
atau tidak demo nya?? Lebih baik saya & Kalian mengatakan kami kafir, kalian \\
demo walaupun berkata seperti demikian. & mengais rejeki dari kami, memakai barang \\
Setidaknya allah liat perjuangan kita & malu dgn perkataan anda, bisa diliat anda \\
bahwasanya kami ini ada pergerakan ketika & pendidikan rendah, makan ciki dl gan \\
islam di injak2. Dari pada anda yg tidak demo & [You named us as infidel. You work for us. \\
sok ikut komentar. Dasar cina kafir! & You use made in China products. Don't \\
[... At least Allah saw my struggle in & you feel ashamed with your words? It \\
defending Islam. In fact, you didn't join the & seems that you are low-educated one. \\
rally and only commented. Such an infidel & ... ] \\
Chinese.] & \\
\hline
\end{tabular}

Source: Compiled by the authors from Instagram of temanahokofficial.

unity in diversity, on 19 November and 4 December. Rather than supporting Ahok explicitly, the goal of this parade was to call on the nation to maintain unity amidst recent tensions. People wearing red and white clothes and traditional attire gathered around Thamrin Boulevard to hold interfaith prayers as well as music and traditional performances. Not only in the offline space, particularly in the city of Jakarta, but also the online space has violent tension broken out. The widespread use of social media enables people to distribute hate speeches as shown in the following Table.

On 24 October, the Jakarta General Elections Commission (KPU) determined the serial numbers for the three pairs of candidates running for the Jakarta 2017 Gubernatorial Elections. The serial numbers of 1, 2 and 3 were obtained consecutively by Agus Harimurti Yudhoyono-Sylviana Murni,
Basuki 'Ahok' Tjahaja Purnama-Djarot Saiful Hidayat and Anies Baswedan-Sandiaga Uno. While Agus-Sylviana has political support from the Cikeas Coalition consisting of the Democratic Party, the National Mandate Party (PAN), the United Development Party (PPP) and the National Awakening Party (PKB), Anies-Sandiaga receives it from Gerindra and the Prosperous Justice Party (PKS). The next Jakarta Gubernatorial Elections between those three pairs reflects national political contestation with three main patrons, namely the preceding President Susilo Bambang Yudhoyono (SBY) (Cikeas Coalition), a previous President Megawati Soekarno Putri (PDI-P) and the losing presidential candidate Prabowo Subianto (Gerindra).

Regardless of Ahok's blasphemy case, the events show the increasingly heated political contestation for the next Jakarta 
Gubernatorial Elections. The contestation not only involves political patrons, but also the militant grassroots. This certainly supports the argument of Berenscholt, Nordholt and Bakker (2016) on the dominance of oligarchic elites and patronage politics in the democratization of Southeast Asia, including Indonesia. However, we believe that migration and ethnicities transforming Jakarta into a cosmopolitan city will also contribute to enhance the deepening civic politics of Jakartans. The recent movements and debate in the civic space, both offline and online, between hard-line Muslims, moderate Muslims and other pluralist groups provide great opportunities for most Indonesians, especially Jakartans, to learn and participate in various forms of civic politics.

\section{Conclusion: Civic or Sectarian Politics?}

The story of Jakarta provides an example of the ways migration and ethnicities influence local politics, both in political discourse and in political systems. Rather than glorifying the widespread use of social media in recent political life, we believe the current political developments are a result of many factors along the historical processes. The fact of Jakarta as a 'host city' of migrants since the colonial time and even after independence has created a multi-ethnic city with a relatively plural identity. While the Old Order introduced diversity and the New Order forced a military line in terms of Jakarta's leadership, the democratic atmosphere of recent local politics encourages more plurality and multiculturalism. Thus, for the first time in history, a Christian Chinese-Indonesian is standing in the Jakarta 2017 Gubernatorial Elections.

The political discourse in the recent Jakarta local politics highlights conservatism versus pluralism as the core of heated discursive debate. The conservatism, which is mostly from hard-line Muslim groups, sees the texts as direct messages from God and demands Islamic purification. These scripturalist networks are becoming popular and control religious institutions, such as mosques, schools and even the Indonesian Ulema Council (MUI) (Kloos \& Berenschot, 2016). Meanwhile, the advocates of pluralism are the minority migrants, including Christians and Chinese-Indonesians, as well as moderate Muslims. The moderate Muslims or substantialists argue for a more flexible interpretation according to modern needs and circumstances (Kloos \& Berenschot, 2017), including voting for non-Muslim leaders. The widespread use of social media speeds up the distribution of hate speech among them and speech may actually reflect the underlying problem of inequality in economic distribution as well as the stratification gap of different social classes within Indonesian society.

Concurrently, migration and ethnicities have brought changes to the political landscape of Jakarta. For the first time, there is public engagement in political movements to support their candidate in the next gubernatorial elections on an independent path with no political party affiliations. While the young people are mostly assumed to be disconnected from traditional electoral politics (Bennett, et.al., 2009; Levine, 2007; Zukin, et.al., 2006 in Lim, 2016), Teman Ahok narrates a contradictory story. The young do not hate politics. They are willing to participate in the 'white' political practices, which they describe as clean and relatively free from the oligarchic elites, including political parties, therefore, they struggle to collect support for their independent candidate. Rather than focusing on narrow identity, they put plurality and socio-economic welfare issues at the top.

Overall, these provide space for all Jakartans to comprehend their citizenship and the civic political culture. Migration and ethnicities have transformed Jakarta into a cosmopolitan city and brought deep consequences to the dynamics of local politics. Will civic politics gain victory in a 
proliferating migrant city, like Jakarta? This remains questionable as the gubernatorial elections will be held on 15 February 2017 and the time of Ahok's blasphemy case has not been decided yet by the court. Surely, these are great tests for the plurality of Jakarta, particularly in terms of ethnicities and religions, as well as the government in terms of economic redistribution among Jakartans.

\section{References}

Abeyasekere, Susan. 1987. Jakarta:A History. Singapore: Oxford University Press.

Ananta, Aris, Evi Nurvidya Arifin, M. Sairi Hasbullah, Nur Budi Handayani and Agus Pramono. 2015. Demography of Indonesia's Ethnicity. Singapore: ISEAS Publishing.

Aprianto, Anton, Muhamad Rizki, Larissa Huda, Prihandoko and Muhammad Kurnianto. 2016. "Dari Pantai Mutiara ke Teras Balai Kota." Tempo, 20-26 June, pp. 30-37.

Aprianto, Anton, Dewi Suci and Indri Maulidar. 2016. "Dari Kepulauan Seribu, Berakhir di Trunojoyo." Tempo, 21-27 November, pp. 30-33.

Aspinall, Edward. 2011. "Democratization and Ethnic Politics in Indonesia: Nine Theses." Journal of East Asian Studies,11, pp. 289319.

Bakker, Laurens. 2016. "Militias, Security and Citizenship in Indonesia." Citizenship and Democratization in Southeast Asia, edited by Ward Berenschot, Henk Schulte Nordholt and Laurens Bakker, pp. 125154. Leiden: Brill.

Barter, Shane Joshua and Isabelle Cote. 2015. "Strife of the soil? Unsettling transmigrant conflicts in Indonesia". Journal of Southeast Asian Studies, Volume, 46, Issue 1, pp. 6085.
Berenschot, Ward, Henk Schulte Nordholt and Laurens Bakker. 2016. "Introduction: Citizenship and Democratization in Postcolonial Southeast Asia." Citizenship and Democratization in Southeast Asia, edited by Ward Berenschot, Henk Schulte Nordholt and Laurens Bakker, pp. 1-30. Leiden: Brill.

Bunnell, Tim and Michelle Ann Miller. 2012. "Jakarta in Post-Suharto Indonesia: Decentralization, Neoliberalism and Global City Aspiration." Space and Polity, pp. 3548.

Castles, Lance. 1967. "The Ethnic Profile of Djakarta.” Indonesia, Vol. 23, pp. 153-204.

Dwifatma, Andina. 2015. "Ahok: Another new hope?" The Jakarta Post (28 March). Retrieved from http://www.thejakartapost. com/news/2015/03/28/ahok-another-newhope.html.

Elyda, Corry. 2015. "Residents support Ahok during Car Free Day." The Jakarta Post (2 March). Retrieved from http://www. thejakartapost.com/news/ 2015/03/02/ residents-support-ahok-during-car-freeday.html.

Fearon, James D. and David D. Laitin. 2011. "Sons of the Soil, migrants and civil war". World Development, Volume 39, No. 2, pp. 199-211.

Firman, Tommy. 2008. "In Search of a Governance Institution Model for Jakarta Metropolitan Area (JMA) under Indonesia's New Decentralisation Policy: Old Problems, New Challenges." Public Administration Development 28, pp. 280-290.

. 2009. "The Continuity and Change in Mega-Urbanization in Indonesia: A Survey of the Jakarta-Bandung (JBR) Development." Habitat International, 33, 4, pp. 327-39.

Hadiz, Vedi. 2010. Localizing Power in PostAuthoritarian Indonesia: A Southeast Asia Perspective. Stanford: Stanford University Press. 
Hamid, Abdul. 2014. "Jokowi's Populism in the 2012 Jakarta Gubernatorial Election." Journal of Current Southeast Asian Affairs, 33, 1, pp. 85-109.

Handoko, Dian Triyuli. 2016. "Basuki Tjahaja Purnama: Lebih Baik Masuk Penjara Ketimbang Mundur," Tempo, 21-27 November, pp. 42.

Heriyanto, Devina. 2016. "Q\&A: Indonesia at Stake in November 4 anti-Ahok Rally?," The Jakarta Post, 3 November. Retrived from http://www.thejakartapost.com/ academia/2016/ 11/03/qa-is-indonesia-atstake-in-nov-4-anti-ahok-rally.html.

Kanumoyoso, Bondan. 2007. "Pengantar: Perubahan Identitas Penduduk Jakarta." Profil Etnik Jakarta, Lance Castles, pp. xixxxi. Jakarta: Masup.

Kloos, David and Ward Berenschot. 2016. "Citizenship and Islam in Malaysia and Indonesia." Citizenship and Democratization in Southeast Asia, edited by Ward Berenschot, Henk Schulte Nordholt, and Laurens Bakker, pp. 178210. Leiden: Brill.

Lim, Merlyna. 2016. "Digital Media and Malaysia's Electoral Reform Movement." Citizenship and Democratization in Southeast Asia, edited by Ward Berenschot, Henk Schulte Nordholt and Laurens Bakker, pp. 211-237. Leiden: Brill.

Miichi, Ken. 2014. "The Role of Religion and Ethnicity in Jakarta's 2012 Gubernatorial Election." Journal of Current Southeast Asian Affairs, 33, 1, pp. 55-83.

Muntaco, Firman. 2006. Gambang Jakarte. Jakarta: Masup.

Murtadho, Roy. 2016. "Aksi Bela Islam: Antara Bela Agama dan Bela Oligarki." Indoprogress, 2 December. Retrieved from http://indoprogress.com/2016/12/aksibela-islam-antara-bela-agama-dan-belaoligarki/.
Nurhasim and Moerat Sitompul. 2016. "Setelah jadi Tersangka." Tempo, 21-27 November, pp. 34-35.

Panitia Penulisan Gubernur Jakarta. 2011. Kepala Pemerintahan Daerah Jakarta.

Prihandoko. 2016. "Parade Pendukung Basuki." Tempo, 21-27 November, pp. 40.

Purnomo, Wayan Agus, Anton Aprianto and Devy Ernis. 2016. "Proposal Dahulu Relawan Kemudian.” Tempo, 20-26 June, pp. 39-40.

Sunudyantoro, Ahmad Faiz, Rezki Alvionitasari, Arkhelaus W. and Nofika Dian Nugroho. 2016. "Ancaman Kedua setelah Tersangka." Tempo, 21-27 November, pp. 38-39.

Suryadinata, Leo, Evi Nurvidya Arifin and Aris Ananta. 2003. Indonesia's Population: Ethnicity and Religion in a Changing Political Landscape. Singapore: ISEAS.

Teresia, Ananda, Raymundus Rikang and Istman M.P. 2016. "Blusukan Mencari Ulama." Tempo, 21-27 November, pp. 3637.

The Jakarta Post. 2016. "No Corruption in Sumber Waras Land Acquisition: KPK." The Jakarta Post (14 June). Retrieved from http://www.thejakartapost.com/news/ 2016/06/14/no-corruption-in-sumberwaras-land-acquisition-kpk.html.

Van Laer, J. and P. Van Aelst. 2010. "Internet and Social Movement Action Repertoires." Information, Communication and Society, 13, 8, pp. 1147-1171.

Windarsih, Ana and Aulia Hadi. 2014. "Aglomerasi Jakarta: Konsep, Problematika, dan Perkembangan Aspek Kelembagaannya." Dinamika Sosial di Kawasan Pusat Aglomerasi Pantura (JABODETABEK, KEDUNGSEPUR, GERBANGKERTOSUSILA: Kasus Kota Jakarta, Semarang, dan Surabaya, edited by Aulia Hadi, Jakarta: PMB-LIPI and PT Gading Inti Prima, pp. 23-48. 